\section{SOI: $1.1 /$ TAS DOI: $10.15863 / \mathrm{TAS}$ International Scientific Journal Theoretical \& Applied Science}

p-ISSN: 2308-4944 (print) e-ISSN: 2409-0085 (online)

Year: 2017 Issue: 08 Volume: 52

Published: $30.08 .2017 \quad$ http://T-Science.org
Vladimir Mihaylovich Shardakov

Lead programmer

postgraduate student of the faculty of mathematics and information technology, Department of applied mathematics

Orenburg State University,

Russia, Orenburg werovulv@inbox.ru

SECTION 4. Computer science, computer engineering and automation.

\title{
THE USE OF MULTIMEDIA TECHNOLOGIES FOR PRODUCING THREE-DIMENSIONAL IMAGES
}

Abstract: The article discusses the theoretical and practical aspects of the relevance of the application possibilities of holography with the purpose of obtaining three-dimensional images of real objects. Was created and described in the basic technology of holographic photolithography. Based on already obtained experience in this field, the analysis and visually reduced the time of receiving a holographic image on the photographic plate. Created a simulation model of the operation for obtaining a holographic image. Next, a scheme for the entry and the restoration of holographic images of the maximum allowable size without losing the quality of the portable real world object on a photographic plate, was formulated and scientifically substantiated requirements to the main parameters of the holograms; it is also experimentally shown the necessity of using this scheme to solve the projection task.

Key words: simulation; Holography; simulation models; multimedia; dynamic flow processing; photolithography.

Language: English

Citation: Shardakov VM (2017) THE USE OF MULTIMEDIA TECHNOLOGIES FOR PRODUCING THREE-DIMENSIONAL IMAGES. ISJ Theoretical \& Applied Science, 08 (52): 122-124.

Soi: http://s-o-i.org/1.1/TAS-08-52-19 Doi: crossef https://dx.doi.org/10.15863/TAS.2017.08.52.19

\section{Introduction}

Currently, much attention is given to $3 \mathrm{D}$ modeling in various fields of science, technology, the arts, including when you create a holography. Holography is a new and significant achievements of modern science and technology, this method contributes to obtaining three-dimensional image, by capturing and playback of the light wave. Standard projection photolithography method, based on the use of expensive projection lens, and also has a large area at the same time limit the exhibited portion of the photoresist. Here, if the wavelength decreases the radiation used, with decreasing size of the display characteristics of the structure can be seen a steady trend towards a decrease in area of the field of the projection lenses. Such devices are used with radiation of a wavelength, with fields $10^{-2}-15 \times 10^{-3} \mathrm{~m}$ in diameter. Devices which work purpose laser radiation with wavelengths $193 \times 10-9$ and $1157 \times 10-9$ , fields have no more units of millimeters. [1]

Using the principles of holography has previously been considered by some authors in the earlier stages of the development of holography. [7, $8,9]$ But, the results needed for practical use was not obtained.
Task definition

For use in short-wavelength photolithography holographic most perspective are suitable recording medium based on glassy chalcogenide semiconductor (GCS) [7]. The use of such media to obtain reliefphase reflection holograms has been demonstrated and held at Vavilov State Optical Institute in 20002005. [2, 11, 12]. But, the results obtained in practical tests still far from ideal. Based on this technology projection holographic submicron photolithography conduct development recording scheme and the reconstruction of holograms, characterized minimum request for temporal coherence of the radiation source.

The scheme of recording and reconstruction of holograms-projectors, providing the minimum requirements for the coherence length of the used radiation sources. The laser, with sufficiently high accuracy, can be regarded as spatially coherent, which is not true of temporal coherence, which establishes a limit on the height golografic scene. Light which is incident on the photosensitive layer from the proximal portion of the object passes the smaller distance than from the more remote. If the path difference of the rays will be greater than the 
length of the temporal coherence of the laser radiation, the interference pattern will not work. [5]

Experimental verification of the suitability of the scheme and obtained by means of a hologram for use in a real process. Experimental verification of the suitability of the scheme simulation was conducted by us using the software CINEMA 4D.[4]

In the proposal work for holography Denisyuk object method has been applied, which consists in the preparation of holographic images in counterpropagating beams. At the base of the method is that the interference field in the region of overlap of the reference and object waves distributed around the crossing space. Applying the optimum light- sensitive materials, a three-dimensional interference pattern may fix. For this purpose, glass photographic plate is used watered layer of gelatin, wherein the silver halide microcrystals distributed. These photographic plate must have full transparency to display. To create an adequate model must be clear physical basis of phenomena. The principle of the creation of the physical fundamentals of holography to produce a holographic image is as follows. A certain perception of the object occurs when light falls on it. In other words, the object itself is not seen directly, but its light image, or in other words, the wave field, which creates the object bouncing off him.

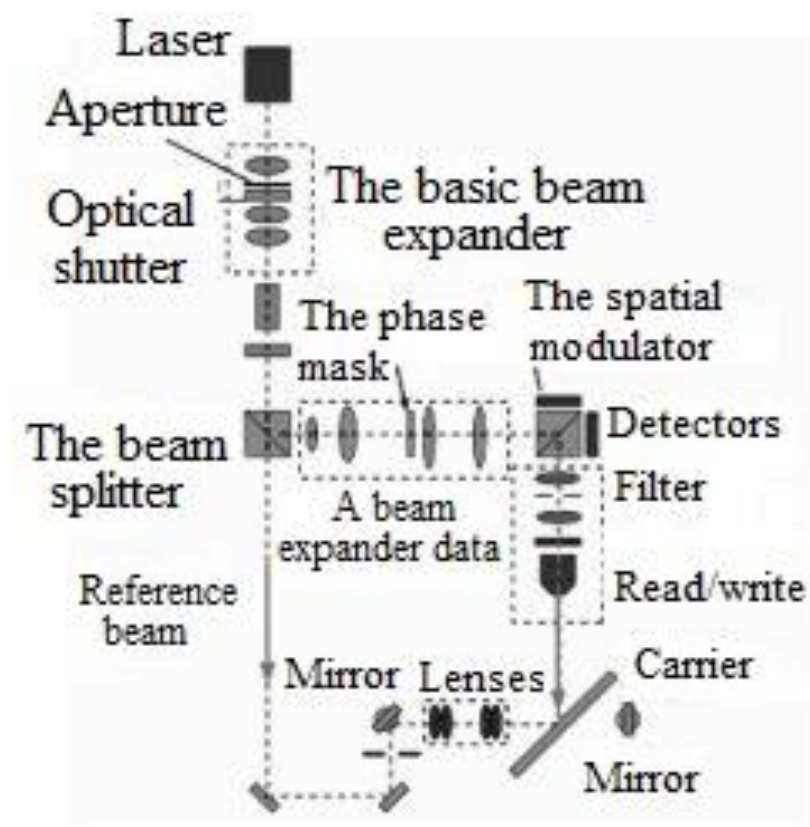

Image 1 - Shows the design scheme developed by the laser system.

\section{Conclusion}

Despite the fact that the concept of holography was invented in 1949, it has received only spread since the early 60 's, after the invention of the laser. This development of the holographic model is one of the main directions in the optical research. It will accelerate the receipt of holographic data in medicine. For example, to obtain an optical hologram eyes, providing a single three-dimensional image of the lens and retina, or acoustical holograms body, which has the important advantage compared with radiographs. Also, the holographic model will be useful in the defense industry for the development and testing of weapons, as well as the topography, to surround the display relief schemes.

So, in the near future, holographic photolithography has all chances to come into our lives and firmly to gain a foothold in it .

\section{References:}

1. Maynard J.D. (1985) Nearfield Acoustic Holography: Theory of Generalized Holography and the Development of NAH / J.D. Maynard, E.G. Williams, Y. Lee // The
Journal of the Acoustical Society of America. 1985. - Vol. 78. - №. 4. - P. 1395-1413

2. Koreshev S.N. (2004) Holographic method for obtaining images with limiting high resolution 


\begin{tabular}{|c|c|c|c|c|c|c|}
\hline Impact Factor: & $\begin{array}{l}\text { ISRA (India) } \\
\text { ISI (Dubai, UAE } \\
\text { GIF (Australia) } \\
\text { JIF }\end{array}$ & $\begin{array}{l}=1.344 \\
=0.829 \\
=0.564 \\
=1.500\end{array}$ & $\begin{array}{l}\text { SIS (USA) } \\
\text { PИНЦ (Russia) } \\
\text { ESJI (KZ) } \\
\text { SJIF (Morocco) }\end{array}$ & $\begin{array}{l}=\mathbf{0 . 9 1 2} \\
=\mathbf{0 . 2 0 7} \\
=\mathbf{3 . 8 6 0} \\
=\mathbf{2 . 0 3 1}\end{array}$ & $\begin{array}{l}\text { ICV (Poland) } \\
\text { PIF (India) } \\
\text { IBI (India) }\end{array}$ & $\begin{array}{l}=6.630 \\
=1.940 \\
=4.260\end{array}$ \\
\hline
\end{tabular}

for extreme shot-wave lithography problems / S.N. Koreshev, V.P. Ratushnyi // Proc. SPIE. 2004. - Vol. 5290. - P. 221-232.

3. Fon Kenigsmark, A. (2008) Masterskaja CINEMA 4D 10. / A. fon Kenigsmark. - M. : MK-Press, 2008. - p. 448.

4. Bykov V.P. (2004) Lazernye rezonatory / V.P. Bykov, O.O. Silichev. - M. : FIZMATLIT, 2004. - p. 320.

5. Denisjuk Ju.N. (1979) Principy golografii / Ju.N. Denisjuk. - L. : Opticheskij institut imeni S.I. Vavilova, 1979. - p. 65.

6. Zhiglinskij A.G. (1983) Real'nyj interferometr Fabri-Pero / A.G. Zhiglinskij, V.V. Kuchinskij. - L. : Mashinostroenie, 1983. - p. 176.

7. Ishhenko E.F. (1980) Otkrytye opticheskie rezonatory / E.F Ishhenko. - M. : Sovetskoe radio, 1980. $-208 \mathrm{p}$.

8. Kartuzhanskij A.L. (1987) Himija i fizika fotograficheskih processov / A.L. Kartuzhanskij, L.V. Krasnyj-Admoni. - L. : Himija, 1987. - p. 137.

9. Koreshev S.N. (2004) Ispol'zovanie metoda golografii dlja poluchenija izobrazhenij dvumernyh ob\#ektov pri reshenii zadach fotolitografii vysokogo razreshenija / S.N. Koreshev, V.P. Ratushnyj // Opticheskij zhurnal. - 2004. - T. 71. - № 10. - pp. 32-39.

10. Ivanov V.M. (2011) Opyt ispol'zovanija i perspektivy razvitija informacionnyh tehnologij v dizajne / V.M. Ivanov, P.A. Orlov, A.A. Holina // Dizajn. Materialy. Tehnologija. 2011. - № 2(17). - pp. 108-112.

11. Koreshev S.N. (2003) Poluchenie besspeklovyh izobrazhenij dvumernyh ob\#ektov mikroskopicheskogo masshtaba metodom golografii / S.N. Koreshev, V.P. Ratushnyj // Optika i spektroskopija. - 2003. - T. 94. - № 1. - pp. 139-142.
12. Pokrovskaja L.L. (2010) Malye predprijatija v sfere informacionnyh tehnologij kak sub\#ekty innovacionnyh processov / L.L. Pokrovskaja // Mir jekonomiki i prava. - 2010. - № 12. - pp. 18-22.

13. Bolodurina I., Parfenov D., Shukhman A. (2013) Efficient access to multimedia resources in distributed systems of distance learning: IEEE Global Engineering Education Conference EDUCON, March 13-15, 2013, Berlin, Germany, pp.1228-1231.

14. Parfenov D., Zaporozhko V., Parfenov I. (2017) Approaches to the description of model massive open online course based on the cloud platform in the educational environment of the university. 4th International KES conference on Smart Education and Smart e-Learning, June 21-23, 2017, Vilamoura, Portugal, pp. 177-191.

15. Stuikys, V., Burbaite, R., Bespalova, K. (2015) The LO Sequencing Problem and Its Solution Using Meta-Programming-Based Approach: 21st International Conference on Information and Software Technologies (ICIST 2015), October 15-16, 2015, Druskininkai, Lithuania, pp. 151-164.

16. Parfenov D.I. (2012) Sravnenie effektivnosti algoritmov dinamicheskogo raspredeleniya dannyih $\mathrm{v}$ oblachnyih hranilischsh sistemyi distantsionnogo obucheniya / D.I. Parfenov // Voronezh: OOO "Izdatelstvo "Nauchnaya kniga", - 2012. T. 50. - № 4.1. - pp. 163-168.

17. Parfenov D.I. (2015) Approaches to the effective use of limited computing resources in multimedia applications in the educational institutions / D.I. Parfenov, I.P. Bolodurina // 2015 5th international workshop on computer science and engineering: information processing and control engineering, wcse 2015ipce. M.: Information Processing and Control Engineering, Programme, - 15-17 April 2015 